\title{
大山川における付着藻類の剥離に必要な フラッシュ放流規模に関する現地実験 〜水力発電用取水堰（大山川ダム）について〜 APPROPRIATE FLUSHING FROM INTAKE DAM (OHYAMAGAWA DAM) FOR HYDROELECTRIC POWER PLANTS TO DETACH ATTACHED ALGAE IN THE OHYAMA RIVER
}

\author{
矢野真一郎 1 ・原川将人 $2 \cdot$ 黄偉 $3 \cdot$ 林琳 $4 \cdot$ 小松利光 5 \\ Shinichiro YANO, Masato HARAKAWA, Huang WEI, Lin LIN and Toshimitsu KOMATSU
1正会員 工博 九州大学大学院准教授 工学研究院環境社会部門（广819-0395 福岡市西区元岡744）
2学生会員 九州大学大学院 工学府海洋システム工学専攻 (同上) \\ 3 工博 中国水利水電科学研究院 (A-1 Fuxing Road, Haidian District, 100038 Beijing, CHINA) \\ 4工修 TOTO株式会社（广802-8601 北九州市小倉北区中島2-1-1） \\ 5フェロー 工博 九州大学大学院特命教授 工学研究院環境社会部門（广819-0395 福岡市西区元岡744）
}

\begin{abstract}
Ohyamagawa Dam is an intake weir for two hydroelectric power plants along the upper Chikugo River, so-called the Ohyama River. After 2002, environmental flow regime has been changed from $1.5 \mathrm{~m}^{3} / \mathrm{s}$ to $4.5 \mathrm{~m}^{3} / \mathrm{s}$ in summer (April-September) and $1.8 \mathrm{~m}^{3} / \mathrm{s}$ in winter for river restoration under regulated condition by dams. But, this improvement of environmental flow regime was not considered to give a satisfactory condition for the river environment. Thus, in 2011 we attempted artificial flushing experiments from the dam to improve it by detaching attached algae on the riverbed material as a possible countermeasure. In-situ measurement for hydraulic conditions and attached algae sampling were conducted during the flushing experiment. As a result of this research, flushing discharge of $40 \mathrm{~m}^{3} / \mathrm{s}$ is the minimum appropriate discharge for the Ohyama River under the realistic restriction.
\end{abstract}

Key Words: attached algae, Chikugo River, flushing, hydroelectric dam

\section{1. はじめに}

2011年3月に発生した東京電力福島第一原子力発電所 の事故に伴い, 我が国の一般世論は脱原発と再生可能工 ネルギーへの支持が大きくなっている. 再生可能エネル ギーのうち最もシェアが大きいのが水力発電であり, 2011年度実績では全発電量の $9.0 \%(863$ 億kWh), 発電容 量は水力全体で $19.2 \%\left(4,842\right.$ 万W) であった ${ }^{1)}$. 一方, 他 の新エネルギーは，発電量で $1.4 \%$, 発電容量で $0.2 \%$ と わずかである ${ }^{1)}$ 。このよう水力発電は電力源として無 視できず，安定性と環境性 $\left(\mathrm{CO}_{2}\right.$ を排出しないという意味 でにも優れ，かつ純国産でありエネルギー安全保障面 でもメリットがある. よって, 今後の電気エネルギー政 策上，水力発電の持続的な利用は重要課題といえる.

水力発電の持続的利用を考える上で，考慮されるべき こととして，(1)出水などの災害一の脆弱性対策，(2)水車
や発電機などの施設改良による発電容量増量，(3)維持流 量の放流やダムの未利用落差を用いた発電の実施2)，(4) ダムの堆砂容量を解放することによる発電容量増量, な どに加えて，(5)河川環境への悪影響を緩和することがあ げられる.このうち(5)にいては，流況改善による緩和 策が考えられる。一般水力発電のうち流れ込文式(水路 式)やダム水路式では, ダム式のようにダム堤体直下で 放流しないため, 発電用水を取水口から離れた下流域に 流している. よって，その区間が減水区間(または無水 区間)となり河川環境の劣化が起こっていた．これに対 する対策として，1988年に国により通達された「発電水 利権の期間更新時における河川維持流量の確保につい て」，いわゆる「発電ガイドライン」により，一定の維 持流量(取水地点集水面積に対寸る比流量で 0.1 $\left.0.3 \mathrm{~m}^{3} / \mathrm{s} / 100 \mathrm{~km}^{2}\right)$ を減水・無水区間に戻すことが義務づけ られた. しかし，放流後の調査では無水状態からは改善 が見られるが，さらに流量を増やすことやフラッシュ放 
流を導入することなどの必要性が指摘されている3).

これまで，フラッシュ放流の事例は我が国だけでも数 多く存在している ${ }^{4-10)}$. 近年のものでは，例えば，赤松 $ら^{8)}$ は室内実験と宮ヶ瀬ダムのフラッシュ放流による現 地実験ならびに数值シミュレーションから，粒径5〜 $10 \mathrm{~mm}$ 程度の砂碩が混入していることが系状藻類の強制 剥離に有効であることを明らかにした。 山内ら ダムのフラッシュ放流について放流時の河川水中に含ま れる植物色素の濃度加ら剥離効果を定量的に明らかにす ることを試みた．また，同じ灰塚ダムについては，椿ら ${ }^{10)}$ が現地調査と数值シミュレーションによりフラッシュ 放流による河床環境の改善効果を検証している.

しかし，フラッシュ放流を実績のないダムで実施する 場合には，目的に適した流量規模や流し方などを予測す るのは一般的には困難である。 また，特に放流流量につ いては，ダムの放流設備や水力発電ダムの電力供給への 影響度などに依存するなど現実的な制約条件から決定さ れることが多い，また，流水中の砂磎の有無により，同 じ流量規模であっても付着藻類の剥離状況が異なる とから，最近は置き砂を併用したフラッシュ放流なども 各地で行われ始めている ${ }^{12)}$.

本論文では, 筑後川上流の大山川にある水力発電用取 水堰である大山川ダムにおいて付着藻類の剥離更新の促 進のための流況制御について調べることを目的に実施さ れたフラッシュ放流実験について報告し，現実的な制約 条件のもとで有効な環境改善効果を得るためのフラッ シュ放流について考察する.

\section{2. 大山川ダムについて}

本研究の対象河川である大山川は, 筑後川上流の松原 ダムから访珠川合流地点までを指すが(図-1), 松原ダム の下流にある大山川ダムは2つの水力発電所(女子畑と柳 又)に導水する取水堰であり, その直下から㺵珠川合流

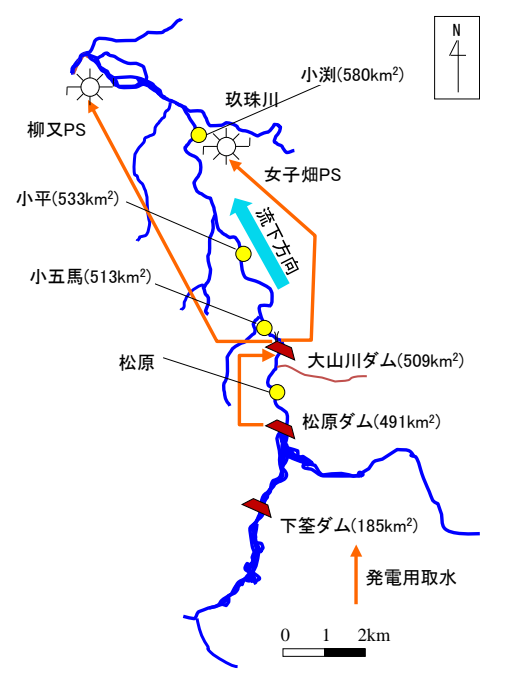

図-1 大山川流域，調査地点とその集水面積
点までが減水区間とみなせる. 2002年より, 河川環境改 善を目的として維持流量の増量が行われており，それま での通年 $1.5 \mathrm{~m}^{3} / \mathrm{s}$ が，3月下旬から9月末までの期間に $4.5 \mathrm{~m}^{3} / \mathrm{s}$ ，それ以外の期間では $1.8 \mathrm{~m}^{3} / \mathrm{s}$ を流している. ま た，松原ダムでもダム式の発電が行われているが，発電 用水の放流口は松原ダム直下ではなく，それより低い大 山川ダムに近い地点に設置されており，そこまでの区間 は減水区間となっている，この区間については，2003年 より通年 $0.5 \mathrm{~m}^{3} / \mathrm{s}$ から通年 $1.5 \mathrm{~m}^{3} / \mathrm{s}$ へ増量されている。これ らの増量は, 地元市民による運動を契機に合意に達して 実施され，その効果についての調査より，ダム建設後に 見られなくなった $30 \mathrm{~cm}$ 以上の尺アユが復活したことな ぞの環境改善が見られたとの結果が出ている ${ }^{13)-15) .}$

その後, さらに増量することが求められており, 関係 者間の協議が進められている. しかし, 維持流量の増量 は水利権をもつ電力会社にとっては減電, 寸なわち減収 に直接結びつくものであり, 合意への進展が見られてい ない. そこで, 本来の川の姿に近づけるための科学的・ 定量的な評価を行い，協議中の維持流量の適正規模を検 討する基礎資料とすることを目的とした社会実験として フラッシュ放流実験を試みることが合意された．フラッ シュ放流には, ダム群によりカットされた数十 $\mathrm{m}^{3} / \mathrm{s}$ 程度 の小規模出水を人為的に復活させて流況の平滑化を防ぎ 自然流況に近づけることが期待される.

\section{3. フラッシュ放流実験について}

本研究で実施したフラッシュ放流実験は，大山川ダム を管理する九州電力(株)の協力のもと，表-1に示す日程 で2011年9月下旬〜10月上旬にかけて計4回と，2012年3 月初めに1回の計5回実施された．本論文では，2011年の 実験についてのみ紹介する.

今回の放流実験の主目的は，ダム下流から玖珠川合流 地点までの大山川全域について付着藻類を剥離するのに 必要な流量規模を求めることである. そのため, 電力事 情が非常に厳しい中であったが，電力会社が許容できる 範囲で大きな水量を放流する計画が立てられた．ピーク 放流量は10～40 $\mathrm{m}^{3} / \mathrm{s}$ まで $10 \mathrm{~m}^{3} / \mathrm{s}$ 刻夕で設定し，3〜4日毎 にピーク流量を大きくしながら計4回実施された。なお， 付着藻類の剥離には最も流速が大きくなるピーク流量の 他に，ピーク流量までの上げ方，ピーク流量の継続時間

表-1 大山川ダムのフラッシュ放流実験の概要

\begin{tabular}{cc|c|c|c|c}
\hline & 第1回 & 第2回 & 第3回 & 第4回 & 第5回 \\
\hline 実施日 & 9 9月26 & 9月29日 & 10月3日 & 10月6日 & $\begin{array}{c}\text { 2012年 } \\
\text { 3月1日 }\end{array}$ \\
\hline 放流時間 & $9: 00 \sim 14: 00$ & $9: 00 \sim 15: 00$ & $8: 30 \sim 15: 00$ & $8: 00 \sim 15: 00$ & $9: 00 \sim 14: 00$ \\
\hline $\begin{array}{c}\text { 最大放流量 } \\
\left(\mathrm{m}^{3} / \mathrm{s}\right)\end{array}$ & 10 & 20 & 30 & 40 & 40 \\
\hline $\begin{array}{c}\text { 維持流量 } \\
\left(\mathrm{m}^{3} / \mathrm{s}\right)\end{array}$ & 4.5 & \multicolumn{3}{|l}{1.8} \\
\hline ピーク継続時間 \\
\hline
\end{tabular}


も重要であるとの指摘 ${ }^{10}$ がある. 本実験では流量の上げ 方については，急激な増水を避けて河道内の安全を確保 するため，ダム操作規則に従って段階的に上げる方法が とられた．ピーク流量の継続時間については，大山川の 下流端で波形が乱れても流量のピークが出現すること， また使用可能な水量の関係から一律2時間と設定された。 ピーク終了後は直ちに維持流量まで減少させた．図-2に 一例として10月6日(ピーク流量 $\left.40 \mathrm{~m}^{3} / \mathrm{s}\right)$ の放流波形を，図 -3にダムに最も近い観測地点(小五馬)における維持流量 流下時と最大流量流下時の状況を示寸，なお，第3回目 (10月3日， $\left.30 \mathrm{~m}^{3} / \mathrm{s}\right)$ の放流直後より大山川ダム下流の維持 流量が夏季の設定である $4.5 \mathrm{~m}^{3} / \mathrm{s}$ から冬季の設定 $1.8 \mathrm{~m}^{3} / \mathrm{s}$ に 移行している．維持流量の減少から最後の10月6日の放 流まで日数が少ないため, 維持流量変化の河床付着藻類 への影響は小さいと判断した。

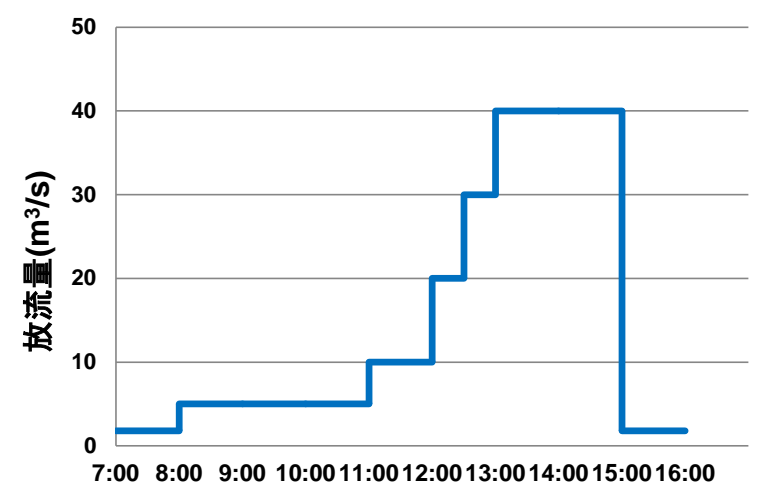

図-2 放流波形の一例（ピーク流量 $40 \mathrm{~m}^{3} / \mathrm{s}$. 大山川ダム地点）

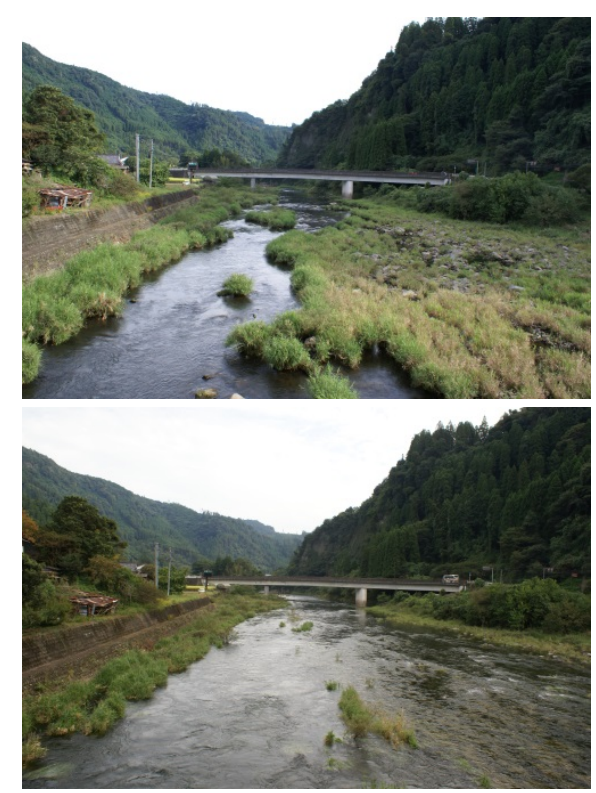

図-3 維持流量流下時 (上, $4.5 \mathrm{~m}^{3} / \mathrm{s}$ ) と最大のフラッシュ放流時 (下, $\left.40 \mathrm{~m}^{3} / \mathrm{s}\right)$ の様子(小五馬地点. 上流向きに撮影)

\section{4. 現地調査について}

\section{(1) 調査地点}

フラッシュ放流実験の実施に併せて9月中旬から10月 中旬にかけて大山川で現地調査を実施した。観測地点は 図-1に示した大山川ダム $(89.9 \mathrm{~km})$ の上流に位置する松原 $\left(92.9 \mathrm{~km}\right.$, 維持流量 $4.5 \mathrm{~m}^{3} / \mathrm{s}$ 時の水深と川幅 : $30 \sim 50 \mathrm{~cm}$, $20 \mathrm{~m}$, 河床勾配：0.0068) と下流に位置する小五馬 (88.5km, 30〜45cm, $25 \mathrm{~m}, 0.0068)$ ・ 小平 $(84.6 \mathrm{~km}, 30 \sim 35 \mathrm{~cm}$, $35 \mathrm{~m}, 0.0085)$ ・ 小㴊 $(77.5 \mathrm{~km}, 30 \sim 50 \mathrm{~cm}, 40 \mathrm{~m}, 0.006)$ の計4地 点である. また，各地点の河床材料は粒径 $10 〜 20 \mathrm{~cm}$ の 礫が中心であり，ダム群建設後のアーマー化で砂はほと んど見られない，植生については，4地点とも河岸沿い にツルヨシ群落が見られた。

これらのうち松原は松原ダムからの放流により流量が $1.5 \mathrm{~m}^{3} / \mathrm{s}$ で一定しているため, 比較対象地点(Reference) と して設定した．ただし，大山川ダム下流3地点とは維持 流量規模が異なっているので，あくまでもフラッシュ放 流のような急激な流況の変動を受けていないという立場 での比較対象である。その他3地点は大山川ダムからの フラッシュ放流の影響を受けるImpact地点となる.

\section{（2）観測機器設置による連続観測}

フラッシュ放流実施期間中の観測地点の物理的な状況 を把握することを目的として，9月25日から10月7日にか けてメモリー式観測機器による連続観測を行った．9月 25日にそれぞれの観測地点の流心部付近の河床に, 電磁 流速計(Compact-EM(以下，全機種アレック電子社製)), Chl.a ・濁度計(Compact-CLW), 水位・水温計(松原を除 く. Compact-TD), DO計(Compact-DOW)をコンクリート ブロックに固定したものを設置した.

\section{(3) 付着藻類調査}

フラッシュ放流による付着藻類の剥離効果と藻類の状 態を調べるために, 前述の4地点で澡類のサンプリング 調查を行った. 付着藻類調查は自然石，タイル，ならび に石と区別した3種類の基盤について行った．河川内に 存在している通常の自然石は場所により流れの速さや日 光の当たり方などの物理的条件，また大きさや形状など の条件が異なっており，付着藻類の量や質を評価する際 にこれらの影響によるばらつきがでるためサンプリング 個数を多くしなければ評価しづらいという久点がある. 本研究グループでは2010年度の藻類調查 ${ }^{15}$ より, 種々の 条件を画一化し，付着藻類の繁茂状況に関する情報を規 格化することを目的に，タイル(商品名「ラグストー ン」, 御影石製, $20 \mathrm{~cm} \times 20 \mathrm{~cm} \times 2 \mathrm{~cm}$, 重量 $2.5 \mathrm{~kg})$ を導入 している. また，現地で自然石表面の付着藻類を全て剥 がしてタイルのそばに再設置したものを石としている.

一方で本実験では，自然石とタイル・石では履歴効果 
が異なっている．まず，自然石については観測毎に現場 で選んでサンプルを採取するため，観測日以前に実施さ れた全てのフラッシュ放流の影響を受けた藻類の剥離効 果を評価することになる。一方，タイル・石については 2012年9月2日に各観測地点に7個ずつ設置した後に, 約2 週間の期間を経て9月16日に藻類の繁茂状態を調べた. その後, 最初の放流実施日(9月26日)の前日である9月 25 日に同観測地点内で大きな岩陰や橋脚の背後などフラッ シュ放流の影響を受けにくい場所に移動して，各フラッ シュ放流前にタイル・石を各 1 個ずつ河道内に戻して各 フラッシュを受けさせた. これによりタイル・石は評価 対象より前のフラッシュの影響を最小限にした評価がで きた. 調查は9月16日(基盤設置2週間後), 25日(第1回フ ラッシュ前日), 27日(第1回1日後, 第2回2日前), 30日 (第2回1日後，第3回3日前)，10月4日(第3回1日後，第4回 2日前)，7日(第4回1日後)，ならびに20日(実験終了2週間 後)の計7回実施した.

毎回の観測では, 過去の調査 ${ }^{15)}$ と同様に各地点で3個 の自然石とタイル・石をそれぞれ1個ずつの計5個のサン プルを採取した．本実験では調査における時間的制約か らタイル・石は1個ずつとしている。採取したサンプル から強熱減量・Chl.aを測定した。 なお，同サンプルか ら付着藻類の種構成を一部のサンプルの夕同定している.

\section{5. 結果と考察}

\section{(1) 連続観測結果について}

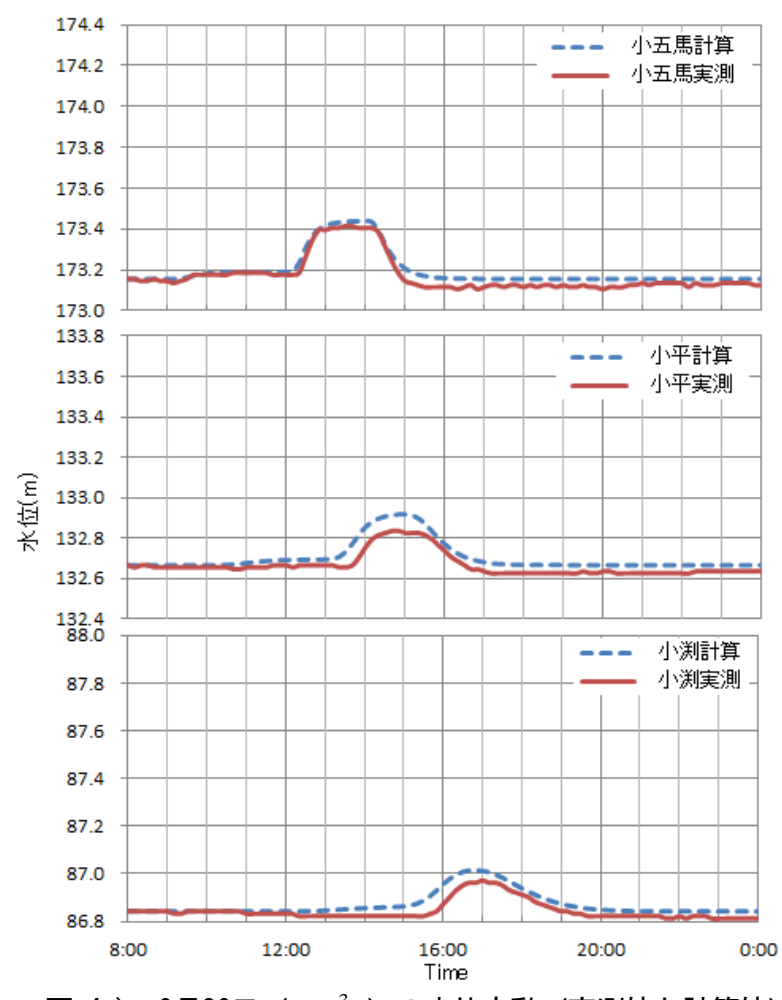

図-4a） 9月26日 $\left(10 \mathrm{~m}^{3} / \mathrm{s}\right)$ の水位変動（実測値と計算値）
図-4に9月26日と10月7日のピーク流量 $10 \mathrm{~m}^{3} / \mathrm{s} と 40 \mathrm{~m}^{3} / \mathrm{s}$ のフラッシュ実験についてImpact地点の3地点における 水位の変動を示す. 上流の小五馬から下流の小㴊までフ ラッシュ放流を受けて水位がピークを示し，それが一定 時間(2時間程度)継続していることが分かる。一方, $10 \mathrm{~m}^{3} / \mathrm{s}$ の場合には最下流の小㴊では波形がなまっており， 継続時間が短くなっていたが，大山川ダムからの 2 時間 のピーク流量の継続時間については大山川全体にピーク 流量の継続を発生させる上での問題はなかったといえる.

また，同図にはMIKE11による1次元不定流計算から得 られた水位の変化も示している．流速については観測か ら良好な結果が得られなかったため, 数值計算結果を用 いて推定している. 計算領域は大山川ダムから小渕地点 までの13.8kmの区間とし，河川断面については国土交通 省が2010年に実施した200mピッチの測量結果を用いた. 上流端はダムからの放流量波形，下流端は実測水位をそ れぞれ境界条件として用いた. マニングの粗度係数は, 各観測地点に設置した水位計のデータと計算が合うよう チューニングした結果, $n=0.08 \mathrm{~m}^{-1 / 3} \mathrm{~s}$ を得た. 同図から分 かるように，おおむ称良好な計算結果を得ている。ここ で得られた粗度係数值はかなり大きい值を示したが, 図 ー3に示した写真のように植生が多いこと，ならびに河床 材料が粒径 $10 \sim 20 \mathrm{~cm}$ の砂が中心であり, 河道内に多数 の巨石(最大径が数m規模) もあるためと推測される.

図-5に10月7日の断面平均流速(計算值), 濁度とChl. $a$ (観測值)の時系列を示す. ダム直下の小五馬を除き，下 流2地点ではピーク流量が到達した際に濁度とChl.aが急 上昇し，その後ピーク流量の継続時間内で減少していく

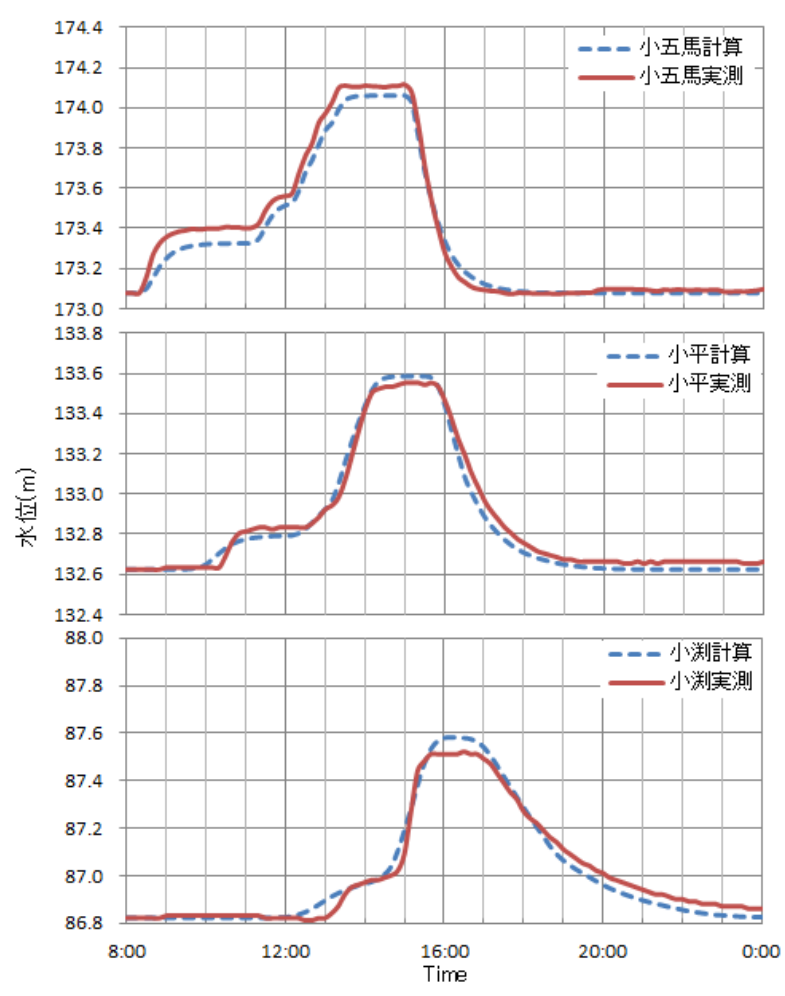

図-4b） 10月7日 $\left(40 \mathrm{~m}^{3} / \mathrm{s}\right)$ の水位変動（実測值と計算值） 
様子が測定されている. 濁度のピーク值は，同じ日には 下流に向けて大きくなり，同じ地点ではピーク流量が大 きくなるにつれて大きくなる傾向性を示した.

\section{(2) 付着藻類調査結果について}

図-6に自然石とタイル・石のChl.a，図-7に各基盤の 強熱減量の経時変化を4地点についてそれぞれ示す. 4 回のフラッシュ放流が行われた日にちとピーク流量が併 記されている. また，自然石については各観測において 採取した3サンプルのデータをそれぞれ示している.
上述のフラッシュ履歴効果による自然石とタイル・石 の間の違いは明確ではなく，両者は概ね同様の傾向を示 している. 今回の実験ではフラッシュ放流としては一般 的に小さいと考えられる10〜 $20 \mathrm{~m}^{3} / \mathrm{s}$ 規模から始めており， 履歴としての影響は小さかったと推定される.

Chl.aについて, フラッシュのインパクトを最も強く 受けるダム直近の小五馬では，ピーク流量が $30 \mathrm{~m}^{3} / \mathrm{s}$ のフ ラッシュ後の10月4日から減少傾向に転じていた．3つの Impact地点の中で中流に位置する小平では $40 \mathrm{~m}^{3} / \mathrm{s}$ 後の 10 月7日には明確な減少傾向を示した. 最下流の小㴊につ
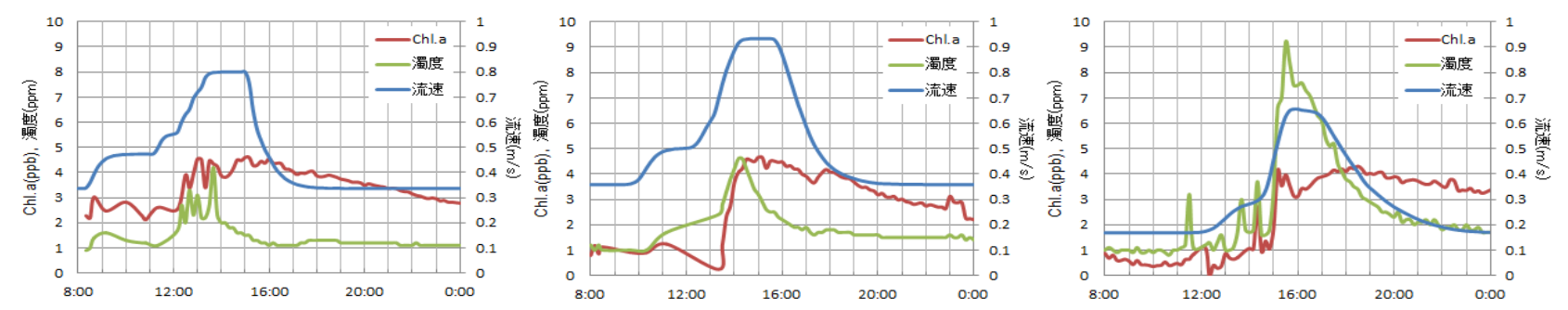

図-5 ダム下流3地点の流速（計算值） - 濁度 - Ch/. aの時間変化 (10月7日. 左から小五馬, 小平, 小㴊)

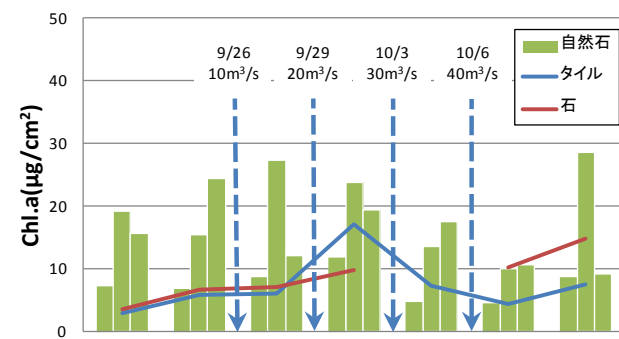

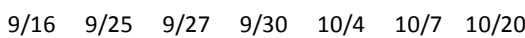
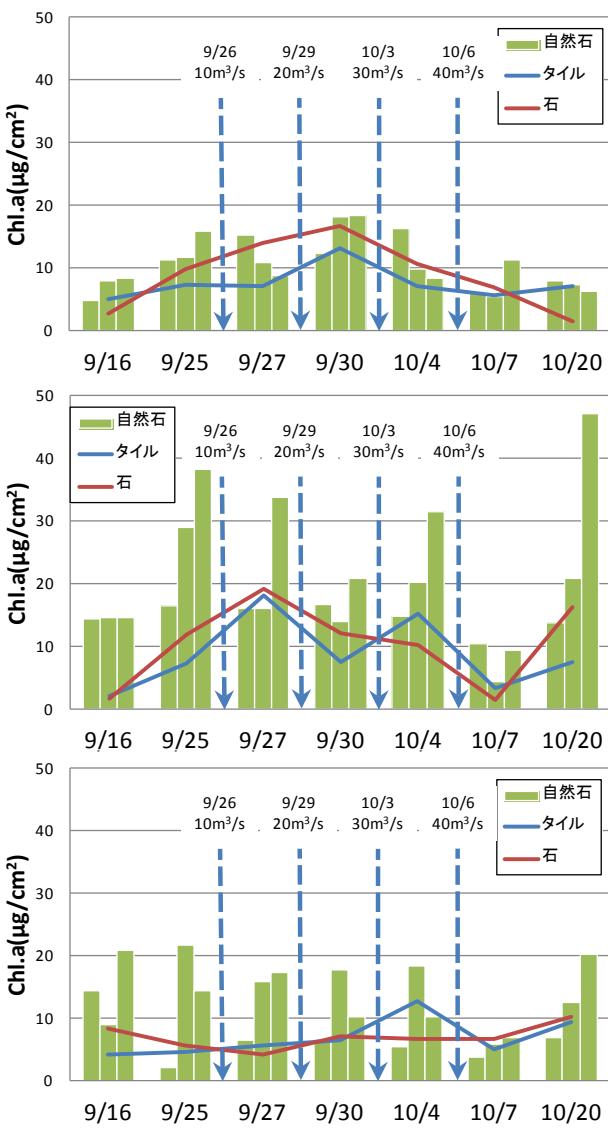

図-6 Ch/. aの変化 (上から松原, 小五馬, 小平, 小㴊)

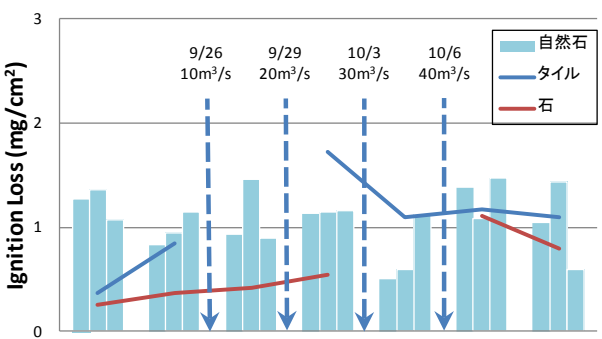

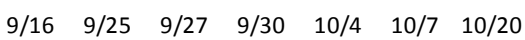
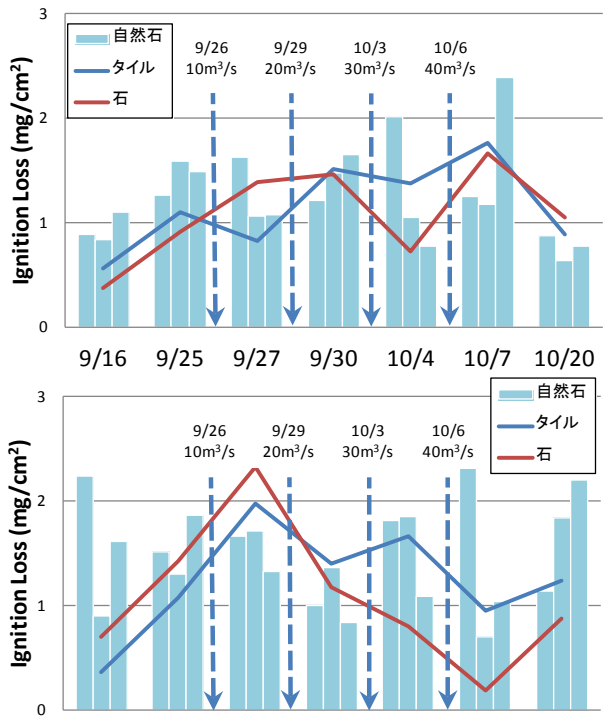

$\begin{array}{lllllll}9 / 16 & 9 / 25 & 9 / 27 & 9 / 30 & 10 / 4 & 10 / 7 & 10 / 20\end{array}$

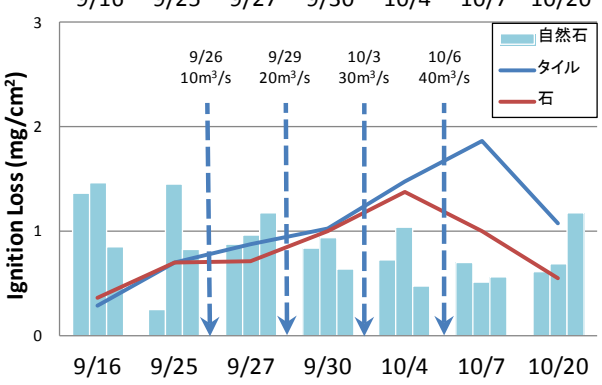

図-7 強熱減量の変化 (上から松原, 小五馬, 小平, 小㴊) 
いても， $40 \mathrm{~m}^{3} / \mathrm{s}$ 後の10月7日に減少がみられた. よって, 大山川全体では流量 $40 \mathrm{~m}^{3} / \mathrm{s}$ が付着藻類の剥離効果をもた ら寸最小流量規模であると考えることができる. なお， Reference地点の松原については, $30 \mathrm{~m}^{3} / \mathrm{s} の$ 放流後から Chl.aが減少しており，小五馬と同様な傾向を示してい る.この自然の減少傾向が，フラッシュを受けた3地点 の結果に対してどの程度含まれているかについては，松 原の流量 $\left(1.5 \mathrm{~m}^{3} / \mathrm{s}\right)$ が大山川ダム下流の維持流量 $4.5 \mathrm{~m}^{3} / \mathrm{s}$ と は異なることから明確ではない. ただし，小平と小㴊の 2地点は，松原とは明らかに傾向性が異なっていること から推定すると松原で見られた傾向性はダム下流Impact 地点では大きく影響していないとも考えることができる。 したがって, ダム下流3地点においてはフラッシュ放流 の効果により藻類が剥離したものと判断している．また, 実験終了2週間後(10月20日)の調查では，概ね上昇傾向を 示しており，再生産が進んだことが分かる.

藻類の種構成については，一部サンプルからのデータ のみであるが，大型系状藻類(Cladophora, Cloniphora, Oedogonium, Ulothrix, Stigeoclonium )が小五馬で $40 \mathrm{~m}^{3} / \mathrm{s}$ 後 に消失し，その2週間後に回復していたことや，藍藻類 のHomoeothrix janthinaがいずれの地点でも優先しており， 小五馬では $30 \mathrm{~m}^{3} / \mathrm{s}$ 後に消失していたことが分かった.

強熱減量については，小五馬で $40 \mathrm{~m}^{3} / \mathrm{s}$ 後に上昇が見ら れるなどフラッシュの効果が明確でない部分もあるが， 小平と小渕では減少傾向が示された。

以上の結果から，大山川全体において付着藻類の強制 剥離を可能とするのに必要なフラッシュ放流規模が最小 で $40 \mathrm{~m}^{3} / \mathrm{s}$ 規模であるといえる. 強制剥離には， $100 \mathrm{~m}^{3} / \mathrm{s}$ 規 模のフラッシュ放流が理想であると考えられるが，社会 情勢などを勘案すると現実的な規模として $40 \mathrm{~m}^{3} / \mathrm{s}$ 程度の フラッシュ放流を実施し, 河川環境を多少とも改善する ことも選択肢の一つになるであろう。

\section{6. おわりに}

筑後川上流の大山川においてフラッシュ放流実験を実 施した. 調查結果より, $40 \mathrm{~m}^{3} / \mathrm{s}$ 規模のフラッシュ放流で 付着藻類の剥離が促進されることが確認された.

課題として，置き砂を併用したフラッシュ放流につい ての検討や，これまでに蓄積された維持流量の増加によ る影響と変動部分としてのフラッシュ放流, ならびに自 然出水による影響を総合的に整理し，現実的な条件下で 大山川のアユを頂点とする河川生態系に対して最も効果 的な放流方法を検討し提案したい，なお，本見解は著者 らの意見であり，関係者の総意ではないことを付記する。

\section{謝辞：}

今回の実験は三隈川・大山川河川環境協議会により実 施された. 詳細計画の策定と当日の実務は, 協議会に設
置された大山川河川環境改善調査WG(筑後川ダム統合管 理事務所, 筑後川河川事務所, 九州電力(株)大分支店, 大分県, 日田市, 水鄉ひた再生委員会, 協力 : 九州大 学)が行った. また，(財)河川環境管理財団の平成23年度 河川整備基金から援助を受けた。藻類種同定に関して井 芹寧氏（西日本技術開発株式会社）にご指導いただいた. ここに記し深甚なる感謝の意を表する.

\section{参考文献 :}

1) 資源エネルギー庁 : エネルギー白書2013, 2013.

2) 大濱隆司, 坂元博巳，冨岡孝仁 : 九州電力における河川維 持流量発電一の取り組み, 電力土木, No.344, pp.44-47, 2009.

3) 国土交通省 : 河川環境改善のための水利調整一取水による 水無川の改善一, 平成13年度〜平成14年度プログラム評価 書, 2003.

4) 角哲也, 塚原千明, 柏井条介 : ダムによる河川流況の変化 とフラッシュ放流に関する考察，ダム技術，第143号， p..40-51, 1998.

5) 辻本哲郎, 増田健一, 寺本敦子, 田代喬 : 試験湛水時のダ ム下流河道の生息環境の変質とその復元のためのフラッ シュの効果の評価, 河川技術に関する論文集, 第5巻, pp.81-86, 1999.

6) 大杉奉功, 尾澤卓思, 小笠原智宏, 角哲也 : フラッシュ放 流による河川掃流効果に関する検討，河川技術に関する論 文集，第6巻，pp.185-190, 2000.

7) 小部貴宣, 浅見和弘, 大杉奉功, 浦上将人, 伊藤尚敬 : 三 春ダムにおけるフラッシュ放流によるダム下流河川の環境 改善について, 応用生態工学, 第8巻, 第1号, pp.15-34, 2005.

8) 赤松良久, 井上麻衣, 池田駿介:フラッシュ放流によるダム 下流の河床付着性藻類の強制剥離に関寸る研究，河川技術論 文集，第14巻，pp.425-430, 2008.

9) 山内鋭司, 岡野隆行, 小松俊晶:フラッシュ放流による付着 藻類剥離効果確認のために灰塚ダムで実施した調查手法の紹 介，河川技術論文集，第16巻，pp.35-40, 2010.

10）椿凉太, 河原能久, 中土井佑輔, 岩苔和広:フラッシュ放流 による河床環境改善効果と放流波形の重要性，河川技術論文 集, 第16巻, pp.523-528, 2010.

11）赤松良久, 池田駿介, 浅野誠一郎, 大澤和敏 : ダム下流 における糸状藻類の強制剥離に関する研究, 土木学会論文 集B, Vol.65, No.4, pp.285-295, 2009.

12) 赤松良久: 置土がダム下流の河川環境に及ぼす影響に関 寸る研究, 環境水理部会研究集会 2012 資料, http://www.jsce.or.jp/committee/hydraulic/kankyousuiri/_worksho p/h24/2012.html, 2012.

13) 矢野真一郎, 齋藤正徳, 井芹寧, 河口洋一, 島谷幸宏, 緒方健，山崎正敏，清野聡子 : 筑後川上流（大山川）にお ける維持流量变化が河川環境に与える影響に関する現地観 測，河川技術論文集，第12巻, pp.443-448,2006.

14) 齋藤正徳, 河口洋一, 矢野真一郎, 井芹寧, 黨秀次郎, 島 谷幸宏, 緒方健, 山崎正敏, 清野聡子 : 筑後川上流域におけ るダム放流量増加が付着藻類に与える影響,水工学論文集, 第51巻, pp.1219-1224,2007.

15) 矢野真一郎, 黄偉, 林琳, 井芹寧, 原川将人 : 筑後川上 流（大山川）における小規模出水の付着藻類相への影響に 関する現地調查, 土木学会論文集B1（水工学），Vol.68, No.4, ,pp.I_757-I_762, 2012.

(2013. 9. 30受付) 